\title{
TENSILE STRENGTH, FRIABILITY AND ORGANIC CARBON IN AN OXISOL UNDER A CROP-LIVESTOCK SYSTEM
}

\author{
Rachel Muylaert Locks Guimarães; Cássio Antonio Tormena ${ }^{1 *}$; Sérgio José Alves²; Jonez \\ Fidalski $^{3}$; Éverton Blainski ${ }^{1}$ \\ ${ }^{1}$ UEM - Depto. de Agronomia, Av. Colombo, 5790 - 87020-900 - Maringá, PR - Brasil. \\ IAPAR - Área de Fitotecnia, C.P. 487 - 86001-970 - Londrina, PR - Brasil. \\ ${ }^{3}$ IAPAR - Área de Solos, C.P. 564 - 87701-970 - Paranavaí, PR - Brasil. \\ *Corresponding author <catormena@uem.br>
}

\begin{abstract}
The crop-livestock system can promote soil compaction in surface layers, mainly due to animal trampling. However, plants and their root growth, in interaction with animal trampling, can decrease the deleterious changes in soil structure caused by this system. Up to the present time, the physical soil modifications in crop-livestock systems, including oat and ryegrass crops for winter animal forages are unknown. The objective of this study was to quantify and to relate tensile strength, friability and soil organic carbon in an Oxisol under a crop-livestock system. The study was conducted in Campo Mourão - Paraná, Brazil. Four forage heights were used for the winter forages: 7, 14, 21 and $28 \mathrm{~cm}$. For each forage height, five soil blocks were randomly collected from each layer of 0 - 0.1, 0.1 0.2 and $0.2-0.3 \mathrm{~m}$ of depth. The increase in carbon content promotes an increase in soil tensile strength at the $0.1-0.2 \mathrm{~m}$ soil depth, this layer having the highest values for tensile strength. The forage height of $21 \mathrm{~cm}$ was found to be the best height for soil friability, and the soil was very friable at this height. Despite a decrease in friability in the upper layers of the soil, the crop-livestock system was not found to be a limiting factor for the subsequent cultivation of annual crops.

Key words: aggregate, soil structure, no-tillage, soil physical quality, microstructure

\section{RESISTÊNCIA TÊNSIL, FRIABILIDADE E CARBONO ORGÂNICO EM UM LATOSSOLO VERMELHO DISTROFÉRRICO SOB INTEGRAÇÃO LAVOURA-PECUÁRIA}

\begin{abstract}
RESUMO: O sistema integração lavoura-pecuária pode promover a compactação das camadas superiores do solo, principalmente devido ao pisoteio animal. Porém, o desenvolvimento das plantas e a produção de raízes, em interação com o pisoteio animal, podem amenizar os efeitos deletérios causados à estrutura do solo por esse sistema. Até agora, são desconhecidas as modificações físicas do solo em sistemas de integração lavoura-pecuária que utilizam aveia e azevém como forrageiras de inverno para a produção animal. Em função disto, o objetivo deste trabalho foi quantificar e relacionar a resistência tênsil, a friabilidade e o teor de carbono orgânico em um Latossolo Vermelho distroférrico sob uso com integração lavoura-pecuária. O experimento foi conduzido em Campo Mourão - Paraná, Brasil. Quatro tratamentos foram utilizados com alturas de pastejo: 7, 14, 21 e $28 \mathrm{~cm}$. Em cada tratamento foram coletados, casualizadamente, cinco blocos de solo nas profundidades de $0-0,10 ; 0,10-0,20$ e 0,20 - 0,30 m. O aumento no carbono orgânico do solo promoveu aumentos da resistência tênsil do solo na camada de 0,10 - 0,20 m, sendo verificados nesta camada os maiores valores de resistência tênsil. A friabilidade do solo foi muito friável com $21 \mathrm{~cm}$ de altura de pastejo. Apesar da diminuição da friabilidade observada nas camadas superficiais, o sistema de integração lavoura-pecuária não é fator limitante aos cultivos anuais subseqüentes.

Palavras-chave: agregado, estrutura do solo, plantio direto, qualidade física do solo, microestrutura
\end{abstract}

\section{INTRODUCTION}

Crop-livestock systems can have positive social, agronomic, economic and environmental effects (Russelle et al., 2007; Franzluebbers, 2007; Allen et al.,
2007). In Southern Brazil, both research and commercial farms have demonstrated that crop-livestock systems can improve net returns in comparison to grain crops alone (Fontaneli et al., 2006). However, soil compaction due to animal trampling decreases the soil 
physical quality needed for growing plants (Imhoff et al., 2000).

Soil physical quality has been evaluated using properties, such as bulk density, porosity, resistance to penetration, and aggregation parameters. Tensile strength is the maximum stress that can be applied to a soil without it undergoing any damage to its structure (Hillel, 1980). The heterogeneity of tensile strength resulting from the networks of cracks and micro-cracks within the soil aggregate has been defined as soil friability (Dexter \& Watts, 2000).

Tensile strength and friability may be influenced by soil organic matter (Rahimi et al., 2000; Watts \& Dexter, 1998). Organic matter can be incorporated into small pores, creating bonds between particles and increasing soil strength in larger aggregate sizes (Guérif, 1994). On the other hand, the specific adsorption of organic compounds onto clays can modify the balance of electrical charges and decrease aggregate tensile strength (Goldberg et al., 1990).

In crop-livestock systems, animal trampling can promote soil compaction in surface layers. However, plants and their root growth, in interaction with animal trampling, can decrease the deleterious changes in soil structure caused by this system. Up to the present time, the physical soil modifications in croplivestock systems, including oat and ryegrass crops for winter animal forages, are unknown. Therefore, the objective of this study was to quantify and to relate tensile strength, friability and soil organic carbon in an Oxisol used on crop-livestock system.

\section{MATERIALAND METHODS}

The study was conducted in Campo Mourão,

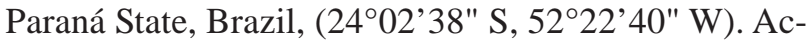
cording to Köepen's classification, the climate is classified as Cfa, mesothermic humid, with $1,340 \mathrm{~mm}$ of rain, concentrated between October and March. The soil is a Typic Haplorthox (Soil Survey Staff, 2006). Particle size analysis (Embrapa, 2006) of the $0-0.15$ m layer presented the following values: $850 \mathrm{~g} \mathrm{~kg}^{-1}$ (clay), $120 \mathrm{~g} \mathrm{~kg}^{-1}$ (silt) and $30 \mathrm{~g} \mathrm{~kg}^{-1}$ (sand).

The experimental area has been cultivated under a no-tillage system for more than 15 years, in a crop rotation with corn, soybean, wheat, canola, black oat and oilseed radish. The experiments started in April 2002, with oat plus ryegrass crops for livestock in winter and soybean in summer. Animal grazing took place yearly, between May and October. For this study four forage heights were used: 7, 14, 21 and $28 \mathrm{~cm}$. The animal stocking rates required to maintain forage height at 7, 14, 21 and $28 \mathrm{~cm}$ were: 2.61, 2.44, 2.25 and 1.82 A.U. ha $^{-1}$, respectively. The sizes of the experi- mental areas were: 1.0, 1.6, 2.1 and 3.3 ha for the 7 , 14, 21 and $28 \mathrm{~cm}$ forage heights, respectively.

The soil was sampled in October 2005. For each forage height, five blocks of soil $(0.15 \times 0.2 \times 0.1$ m) were collected from $0-0.1,0.1-0.2$ and 0.2 $0.3 \mathrm{~m}$ layers. The soil blocks were wrapped in plastic film immediately after removal to maintain soil water content and the integrity of the samples until their arrival at the laboratory. Carefully, the blocks were manually broken up into their individual aggregates. Aggregates were then air-dried for $36 \mathrm{~h}$ and submitted to a final drying at a constant temperature of $40^{\circ} \mathrm{C}$ for 48 h. The aggregates were passed on $12.5 \mathrm{~mm}$ and 19 $\mathrm{mm}$ diameter opening sieves, and the fraction between then selected and separated into individual packs until the tensile strength test was carried out. These sizes aggregates were chosen partly because in this range they are easier to handle and measure and partly because this is the range of aggregate sizes normally obtained by soil tillage (Imhoff et al., 2002). For the measurement of tensile strength, 60 aggregates were separated from each soil block and crushed in individual tests. Before the tensile strength tests, each aggregate was precisely weighed. The indirect tension test was carried out using an electronically controlled loading frame, with an electronic load cell with a capacity of $20 \mathrm{~kg}$, coupled to a computer for data acquisition and storage. The equipment applied a constant strain rate of $0.03 \mathrm{~mm} \mathrm{~s}^{-1}$ until the aggregate failed; i.e., until it had a visible formation of a continuous crack running approximately between the polar diameters. After the test, the aggregates were oven dried to determine residual water content

The effective diameter of each aggregate was calculated following Watts \& Dexter (1998):

$\mathrm{D}=\mathrm{D}_{\mathrm{m}}\left(\mathrm{M} / \mathrm{M}_{\mathrm{m}}\right)^{1 / 3}$

where $\mathrm{D}$ is the effective diameter (mm), Dm is the mean diameter $(\mathrm{mm}), \mathrm{M}$ is the dry mass of an individual aggregate (g) and $\mathrm{M}_{\mathrm{m}}$ is the mean mass of the aggregates of the samples. The tensile strength was calculated following Dexter \& Kroesbergen (1985):

$\mathrm{RT}=0.576\left(\mathrm{P} / \mathrm{D}^{2}\right)$

where 0.576 is the proportionality constant, $\mathrm{P}$ is the applied force at failure (N) and D is the effective diameter of each aggregate $(\mathrm{m})$.

Soil friability (adimensional) was calculated by the coefficient of variation method proposed by Watts \& Dexter (1998):

$\mathrm{F}=\frac{\sigma_{\mathrm{Y}}}{\mathrm{Y}} \pm \frac{\sigma_{\mathrm{Y}}}{\mathrm{Y} \sqrt{2 \mathrm{n}}}$ 
where $\mathrm{F}$ is soil friability, $\sigma_{\mathrm{Y}}$ is the standard deviation of the measured values of tensile strength, $\mathrm{Y}$ is the mean of measured values of tensile strength and $n$ is the number of replications. The criteria established by Imhoff et al. (2002) were used to classify soil friability as: not friable $(<0.1)$, slightly friable $(0.1-0.2)$, friable $(0.2-0.5)$, very friable $(0.5-0.8)$ and mechanically unstable $(>0.8)$.

Soil organic carbon (SOC) was determined for each soil sample after the tension test and after aggregates had been oven dried at a constant temperature of $40^{\circ} \mathrm{C}$. The samples were passed through a $2 \mathrm{~mm}$ opening sieve and mixed. SOC was determined according to the Walkley \& Black method (Embrapa, 1997).

The data were tested for normality using the ShapiroWilk statistics (Statistical Analyses System Institute, 1999). The soil water content of the aggregates was evaluated using a significance level of 1\% (Statistical Analyses System Institute, 1999). Analyses of variance were calculated through a randomized experiment on a split-plot design with five repetitions. The main factor for the split-plot design model was the depth, and the subplot-factor was the forage height. Differences between variable values were compared using the Tukey test $(p<0.05)$. These statistical tests were performed using the software Sisvar (Ferreira, 2007). Regression analyses were carried out on the mean values of the five repetitions for each variable by forage height, and linear coefficients were submitted to t-tests (Statistical Analyses System Institute, 1999).

\section{RESULTS AND DISCUSSION}

Statistical moments for tensile strength, friability and SOC indicate that the present study data fit a normal distribution (Table 1). These results are similar to those of Bartoli et al. (1992) and Dexter \& Watts (2000). However, Perfect et al. (1995), Imhoff et al. (2002) and Blanco-Canqui et al. (2005) have reported log-normal distribution for soil tensile strength data. No differences in the soil water content of the aggregates (mean value $\left.=0.03 \mathrm{~g} \mathrm{~g}^{-1}\right)$ were found $(p<0.01)$. Therefore, the tensile strength values reflect only the effects of the different forage heights. The interaction between sample depth and forage height was significant at $p<0.25$ for tensile strength, at $p<0.19$ for SOC, maximum and mean friability, and at $p<0.16$ for minimum friability (Table 2).

Table 1 - Statistic moments for tensile strength, friability and soil organic carbon (SOC) for four forage heights and three soil depths in a crop livestock system.

\begin{tabular}{|c|c|c|c|c|c|c|c|c|c|c|c|c|}
\hline \multirow[t]{3}{*}{ Variable } & \multicolumn{12}{|c|}{ Treatments (forage height and sample depth) } \\
\hline & \multicolumn{3}{|c|}{$7 \mathrm{~cm}$} & \multicolumn{3}{|c|}{$14 \mathrm{~cm}$} & \multicolumn{3}{|c|}{$21 \mathrm{~cm}$} & \multicolumn{3}{|c|}{$28 \mathrm{~cm}$} \\
\hline & $10^{(1)}$ & $20^{(2)}$ & $30^{(3)}$ & $10^{(1)}$ & $20^{(2)}$ & $30^{(3)}$ & $10^{(1)}$ & $20^{(2)}$ & $30^{(3)}$ & $10^{(1)}$ & $20^{(2)}$ & $30^{(3)}$ \\
\hline & \multicolumn{12}{|c|}{ Tensile strength $(\mathrm{kPa})$} \\
\hline Minimum & 31 & 27 & 25 & 33 & 28 & 22 & 23 & 26 & 26 & 26 & 30 & 25 \\
\hline Mean & 75 & 75 & 64 & 92 & 82 & 74 & 73 & 93 & 63 & 79 & 86 & 66 \\
\hline Maximum & 155 & 182 & 174 & 204 & 199 & 200 & 169 & 283 & 151 & 171 & 234 & 182 \\
\hline Std dev ${ }^{(4)}$ & 28.3 & 30.8 & 28.5 & 34.9 & 34.6 & 35.1 & 32.8 & 46.7 & 24.8 & 32.6 & 37.0 & 30.9 \\
\hline $\mathrm{CV}^{(5)}$ & 0.38 & 0.41 & 0.45 & 0.38 & 0.42 & 0.47 & 0.45 & 0.50 & 0.39 & 0.42 & 0.43 & 0.47 \\
\hline \multirow[t]{2}{*}{$p<\mathrm{W}^{(6)}$} & 0.77 & 0.31 & 0.85 & 0.32 & 0.42 & 0.54 & 0.07 & 0.42 & 0.95 & 0.03 & 0.29 & 0.39 \\
\hline & \multicolumn{12}{|c|}{ Friability (adimensional) } \\
\hline Minimum & 0.33 & 0.36 & 0.38 & 0.34 & 0.36 & 0.42 & 0.40 & 0.45 & 0.33 & 0.37 & 0.38 & 0.41 \\
\hline Mean & 0.38 & 0.41 & 0.45 & 0.38 & 0.42 & 0.47 & 0.45 & 0.50 & 0.39 & 0.42 & 0.43 & 0.47 \\
\hline Maximum & 0.41 & 0.45 & 0.48 & 0.42 & 0.46 & 0.52 & 0.50 & 0.56 & 0.41 & 0.46 & 0.47 & 0.51 \\
\hline $\operatorname{Std} \operatorname{dev}^{(4)}$ & 0.08 & 0.09 & 0.08 & 0.03 & 0.07 & 0.06 & 0.09 & 0.07 & 0.09 & 0.04 & 0.08 & 0.09 \\
\hline CV(5) & 21.6 & 21.2 & 17.9 & 8.3 & 16.2 & 13.2 & 20.6 & 14.8 & 24.2 & 10.7 & 18.9 & 19.9 \\
\hline \multirow[t]{2}{*}{$p<\mathrm{W}^{(6)}$} & 0.79 & 0.03 & 0.48 & 0.44 & 0.29 & 0.54 & 0.86 & 0.94 & 0.03 & 0.80 & 0.72 & 0.41 \\
\hline & \multicolumn{12}{|c|}{ Soil organic carbon $\left(\mathrm{g} \mathrm{dm}^{-3}\right)$} \\
\hline Mean & 17.2 & 12.4 & 12.0 & 20.9 & 17.5 & 11.7 & 26.3 & 18.5 & 14.6 & 21.5 & 16.8 & 12.5 \\
\hline Std $\operatorname{dev}^{(4)}$ & 1.5 & 2.3 & 3.1 & 1.6 & 3.9 & 2.6 & 2.1 & 1.2 & 3.6 & 1.8 & 2.8 & 1.4 \\
\hline $\mathrm{CV}^{(5)}$ & 8.5 & 18.9 & 26.3 & 7.5 & 22.2 & 22.5 & 7.9 & 6.3 & 24.8 & 8.4 & 16.8 & 11.5 \\
\hline$p<\mathrm{W}^{(6)}$ & 0.10 & 0.11 & 0.33 & 0.41 & 0.19 & 0.53 & 0.86 & 0.49 & 0.03 & 0.69 & 0.29 & 0.35 \\
\hline
\end{tabular}

${ }^{(1)} 0$ - 0.1 m depth. ${ }^{(2)} 0.1$ - 0.2 m depth. ${ }^{(3)} 0.2$ - 0.3 m depth. ${ }^{(4)}$ Standard deviation. ${ }^{(5)}$ Coefficient of variation (\%). ${ }^{\left({ }^{6}\right)}$ Probability obtained by Shapiro-Wilk test $(p<0.01)$. 
SOC content was different in the three layers, with the highest value $\left(21.5 \mathrm{~g} \mathrm{~kg}^{-1}\right)$ at $0-0.1 \mathrm{~m}$ of depth, the intermediate value $\left(16.3 \mathrm{~g} \mathrm{~kg}^{-1}\right)$ at $0.1-0.2 \mathrm{~m}$ of depth and the lowest value $\left(12.7 \mathrm{~g} \mathrm{~kg}^{-1}\right)$ at $0.2-0.3$ $\mathrm{m}$ (Figure 1a). The crop residues on the soil surface increased the SOC, contributing to the organic carbon gradient through the layers (Hao \& Kravchenko, 2007; Tormena et al., 2004).

Differences in SOC were found among the different forage heights (Figure 1b). The height of $21 \mathrm{~cm}$ had the highest mean SOC value $\left(19.8 \mathrm{~g} \mathrm{~kg}^{-1}\right)$. There was no difference between the SOC values for the heights of 28 and $14 \mathrm{~cm}$, which showed intermediate values, and the height of $7 \mathrm{~cm}$ showed the lowest SOC value $\left(13.9 \mathrm{~g} \mathrm{~kg}^{-1}\right)$. These results are probably linked to the residual biomass of oat and ryegrass left after grazing, with the least residual biomass being found on the surface of the soil with a forage height of $7 \mathrm{~cm}$ due to the higher grazing pressure. Conversely, for the forage height of $14 \mathrm{~cm}$, the decrease in grazing pressure, in comparison to that at $7 \mathrm{~cm}$, resulted in an increase in residual biomass from the plants. Despite having the low-

Table 2 - F probability obtained by analysis of variance for factors depth and treatment (forages height) to tensile strength, friability and soil organic carbon variables.

\begin{tabular}{lccccc}
\hline \multirow{2}{*}{ Factor } & Tensile strength & \multicolumn{2}{c}{ Friability } & maximum & \multirow{2}{*}{ Organic Carbon } \\
\cline { 3 - 5 } & & minimum & mean & 0.43 & $<0.01$ \\
Depth & 0.01 & 0.43 & 0.41 & 0.62 & $<0.01$ \\
Treatment & 0.11 & 0.59 & 0.58 & 0.19 & 0.19 \\
\hline Depth $\times$ treatment & 0.25 & 0.16 & 0.19 & & \\
\hline
\end{tabular}
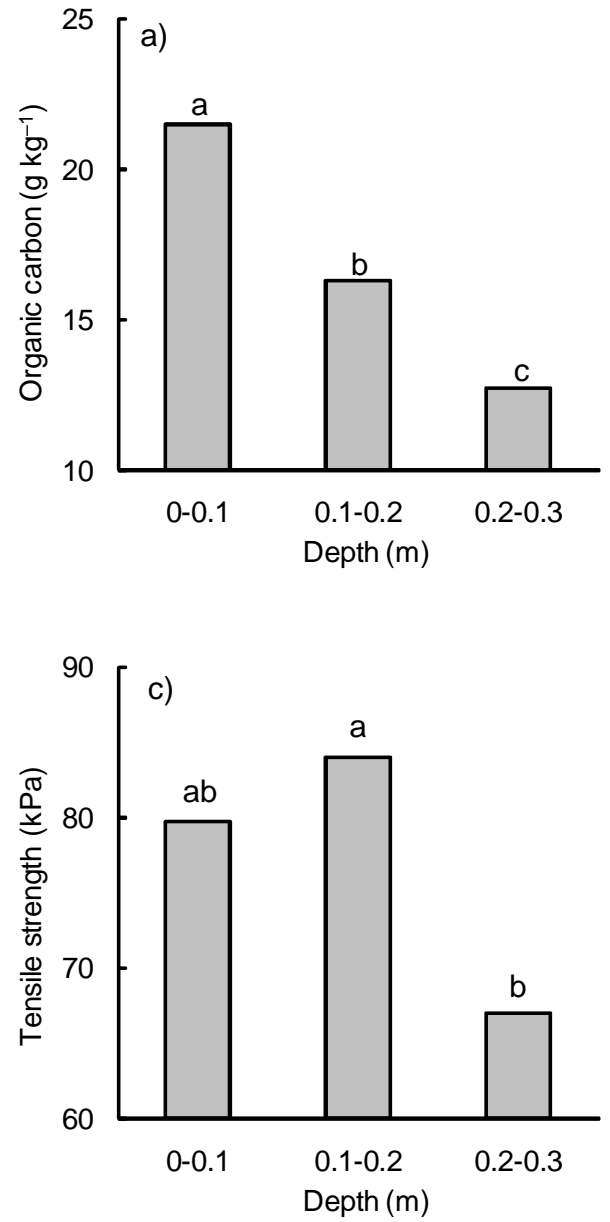
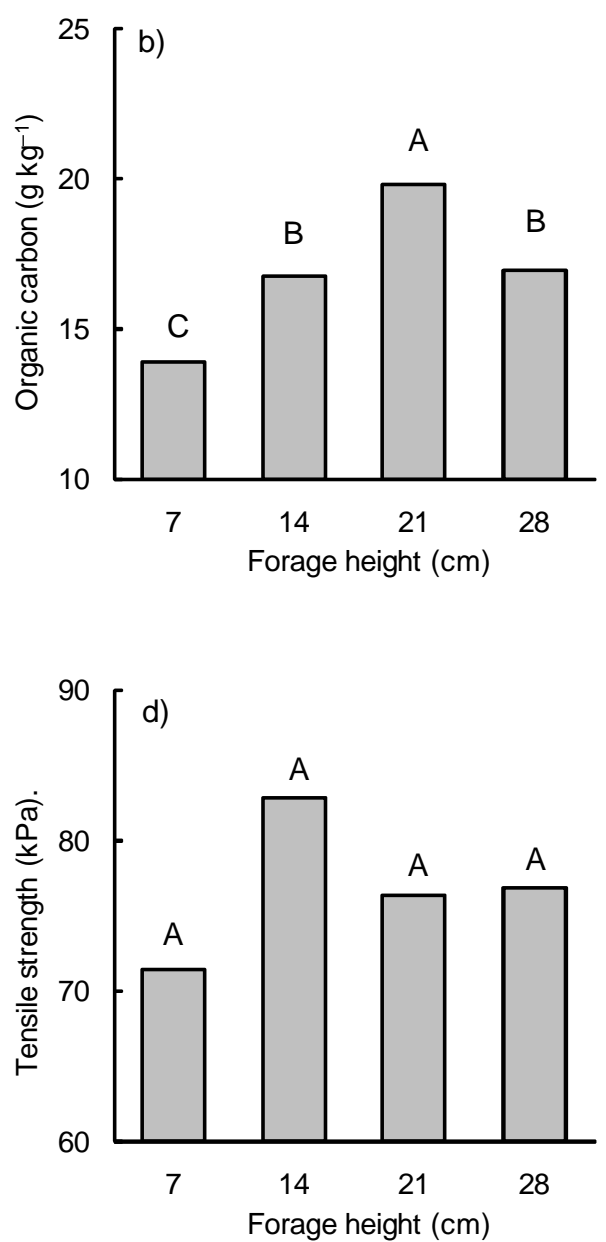

Figure 1 - Soil organic carbon by depth (a) and forage height (b), soil tensile strength by depth (c) and forage height (d). Same letters do not differ (Tukey test, $p<0.05$ ). 
est grazing pressure, the forage height of $28 \mathrm{~cm}$ had a similar SOC content to that found at $14 \mathrm{~cm}$, and it was hypothesized that this happened because the oat plants finished their cycles before the ryegrass plants and that the oat straw blocked ryegrass growth. Therefore, this fact counter-balanced the lowest grazing pressure found at $28 \mathrm{~cm}$, leading to lower SOC values in comparison to those found at $21 \mathrm{~cm}$, and maintenance of similar levels to those found at $14 \mathrm{~cm}$ (Figure 1b).

The highest values for tensile strength were found in the $0.1-0.2 \mathrm{~m}$ layer $(\mathrm{p}<0.05)$ and the lowest values in the $0.2-0.3 \mathrm{~m}$ layer(Figure 1c).A tendency for intermediate values was observed in the $0-0.1 \mathrm{~m}$ layer. In the $0.1-0.2 \mathrm{~m}$ layer tensile strength increased with increases in SOC content (Figure 2a): a positive and strong correlation between these two variables was found (r2=0.81). Conversely, Tormena et al. (2008) found a negative correlation between SOC and tensile strength. SOC should be associated to an increase in tensile strength because it acts as an aggregating agent, stabilizing the microaggregates and thereby helping to an increased tensile strength, according to Guérif
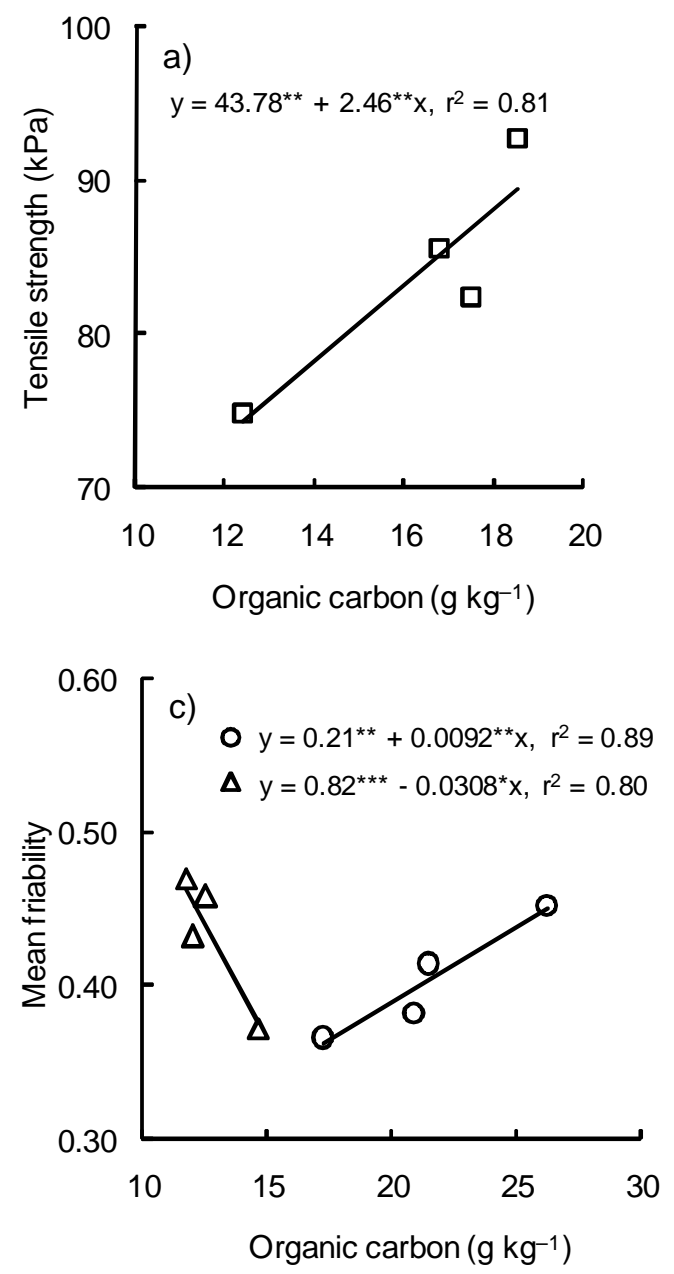

(1994). The 0.1 - $0.2 \mathrm{~m}$ layer was more strongly affected by animal trampling than the $0-0.1 \mathrm{~m}$ layer, because the root systems of the oat and ryegrass crops increased soil resilience in the surface layer. In addition, the root systems promoted increases in fail zones inside the aggregates of the $0-0.1 \mathrm{~m}$ layer, which was magnified by the wet and dry cycles of the soil. In the 0.2 - $0.3 \mathrm{~m}$ layer, neither animal trampling nor plant roots had a strong enough effect to modify the tensile strength of the soil (Figure 1c).

Differences were not found $(p<0.05)$ in tensile strength values among the different forage heights (Figure 1d). However, a tendency of reduced tensile strength values was observed for the forage height of $7 \mathrm{~cm}$, probably due to the apical meristems of oat plants being cut off, allowing the ryegrass plants to achieve better growth due to a reduction in competition between the two species. As the ryegrass has a more aggressive root system than the oat plant, its continuous growth and death may have contributed to a decrease in soil tensile strength. These results showed that a plant with an aggressive root growth system,
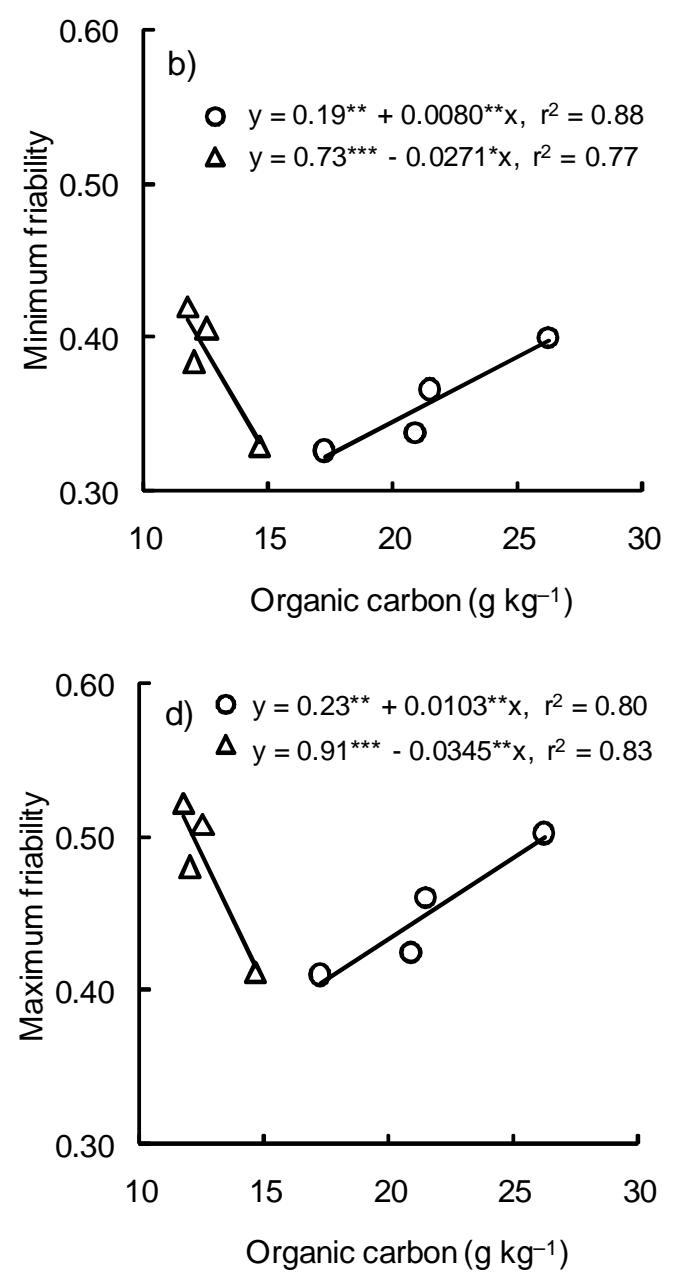

Figure 2 - Tensile strength (a) and friability (b, c e d) in correlation with soil organic carbon, to the depth of 0 - $0.1 \mathrm{~m}(\mathrm{O}), 0.1-0.2 \mathrm{~m}$ $(\square)$ and $\left.0.2-0.3 \mathrm{~m}(\triangle) .{ }^{* * *}(p<0.05),{ }^{* *}(p<0.10),{ }^{*} p<0.15\right)$ using t test. 
like ryegrass, could prevent soil structure degradation in a crop-livestock system.

The minimum, mean and maximum friability values for the forage height of $21 \mathrm{~cm}$ at the depth of 0.1 - 0.2 m (Figure 3 ) were different $(p<0.05)$. This behavior is probably related to the fact that this forage height treatment had the highest SOC values (Figure 1b). A positive correlation between SOC and friability was observed (Figures 2b, c and d ) at $0-0.1 \mathrm{~m}$ of depth $\left(r^{2}=0.88,0.89\right.$ and 0.80 for minimum, mean and maximum friability, respectively) which is explained by the fact that this soil depth had the highest SOC incorporation (Figure 1a). An increase in SOC establishes a well-developed soil structure hierarchy, which results in a wide range of aggregate tensile strengths and an increase in soil friability (Watts \& Dexter, 1998). Organic fragments of crop residues are generally supposed to induce weak sites, as well as soil porosity, thereby contributing to increased soil friability.

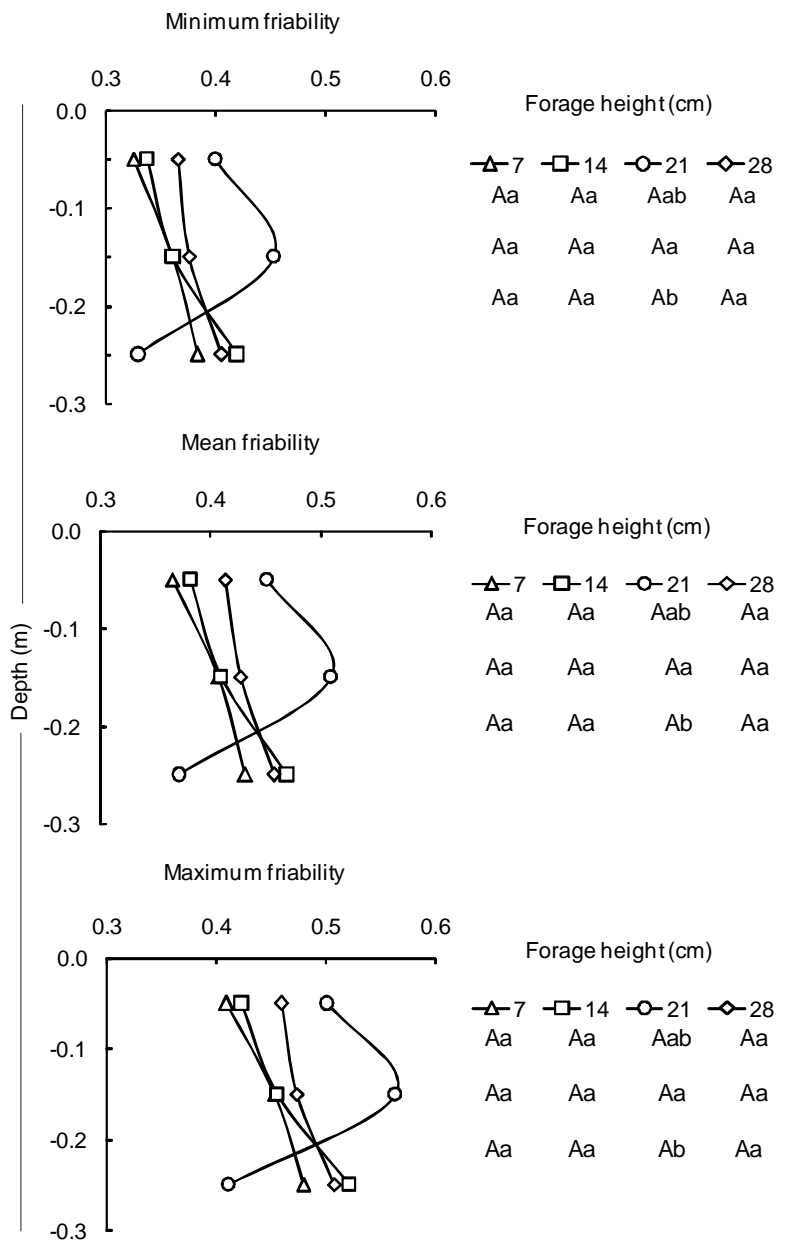

Figure 3 - Soil friability to forage height of 7, 14, 21 and $28 \mathrm{~cm}$. Capital letters compare the forage heights in each depth, and small letters compare the forage heights among the depths $(p<0.05)$. The letters sequence corresponds on treatments $7,14,21$ and $28 \mathrm{~cm}$ on columns for the layers at $0-0.1 ; 0.1-0.2$ and $0.2-0.3 \mathrm{~m}$ depth.
At the depth of $0.2-0.3 \mathrm{~m}$, the minimum, mean and maximum friabilities were negatively correlated with SOC $\left(\mathrm{r}^{2}=0.77,0.80\right.$ and 0.83$)$, indicating that increases in SOC cause a decrease in soil friability (Figures 2b, c and d), probably due to the aggregating effects of SOC. This effect may be related to the quality of the SOC and its interaction with inorganic soil components, especially $\mathrm{Fe}$ and $\mathrm{Al}$ oxides. This soil friability behavior may be explained by the narrow range of tensile strength found in this layer due to the reduced influence of soil management at lower depths. The friability of the soil was classified as friable in the $0-0.1 \mathrm{~m}$ layer and in the $0.1-0.2 \mathrm{~m}$ layer for the forage heights of 7, 14 and $28 \mathrm{~cm}$, and very friable in the $0.2-0.3 \mathrm{~m}$ layer for the forage heights of 14 and $28 \mathrm{~cm}$, showing that soil friability reductions occur in the surface layer (Table 1 ). Soil friability was also very friable in the $0.1-0.2 \mathrm{~m}$ layer and friable in the 0.2 $0.3 \mathrm{~m}$ layer for the forage height of $21 \mathrm{~cm}(p<0.05)$, suggesting a vertical heterogeneity in the physical condition of the soil. Therefore, it is necessary to maintain a minimum forage height of $21 \mathrm{~cm}$ in order to reduce the effects of animal trampling on the physical and structural conditions of the soil, as measured by soil tensile strength and friability.

\section{ACKNOWLEDGMENTS}

The second author acknowledges to CNPq for a granted scholarship.

\section{REFERENCES}

ALLEN, V.G.; BAKER, M.T.; SEGARRA, E.; BROWN, C.P. Integrated irrigated crop-livestock systems in dry climates. Agronomy Journal, v.99, p.346-360, 2007.

BARTOLI, F. BURTIN, G.; GUÉRIF, J. Influence of organic matter on aggregate in Oxisols rich in gibbsite or in goethite. II. Clay dispersion, aggregate strength and water-stability. Geoderma, v.54, p.259-274, 1992

BLANCO-CANQUI, H.; LAL, R.; OWENS, L.B.; POST, W.M.; IZAURRALDE, R.C. Mechanical properties and organic carbon of soil aggregates in the Northern Appalachians. Soil Science Society of America Journal, v.69, p.1472-1481, 2005.

DEXTER, A.R.; KROESBERGEN, B. Methodology for determination of tensile strength of soil aggregates. Journal of Agricultural Engineering Research, v.31, p.139-147, 1985.

DEXTER, A.R.; WATTS, C. Tensile strength and friability. In: SMITH, K.; MULLINS, C. (Ed.) Soil and environmental analysis; physical methods. 2 ed. New York: Marecel Dekker, 2000. p.401-430.

EMPRESA BRASILEIRA DE PESQUISA AGROPECUÁRIA EMBRAPA. Centro Nacional de Pesquisa de Solos. Manual de métodos de análise de solo. 2.ed. Rio de Janeiro: CNPS, 1997. 212p.

EMPRESA BRASILEIRA DE PESQUISA AGROPECUÁRIA. EMBRAPA. Centro Nacional de Pesquisa de Solos. Sistema Brasileiro de Classificação de Solos. 2.ed. Rio de Janeiro: Embrapa Solos, 2006. 306p. 
FERREIRA, D.F. Programa Sisvar: versão 5.0. Lavras: UFLA, 2007. Available at http://www.dex.ufla.br/ danielff/softwares.htm. Accessed 24 Jan. 2008.

FONTANELI, R.S.; SANTOS, H.P.; MORI, C. Lucratividade e risco de sistemas de produção de grãos com pastagens, sob sistema plantio direto. Ciência Rural, v.36, p.51-57, 2006.

FRANZLUEBBERS, A.J. Integrated crop-livestock systems in the southeastern USA. Agronomy Journal, v.99, p.361-372, 2007.

GOLDBERG, S.; KAPOOR, B.S.; RHOADES, J.D. Effect of aluminum and iron oxides and organic matter on flocculation and dispersion of arid zone soils. Soil Science, v.150, p.588593, 1990.

GUÉRIF, J. Effects of compaction on soil strength parameters. In: SOANE, B.D.; OUWERKERK, C. van (Ed.) Soil compaction in crop production. Amsterdan: Elsevier Science, 1994. chapter 9, p.191-213.

HAO, X.; KRAVCHENKO, A.N. Management practice effects on surface soil total carbon: differences along a textural gradient. Agronomy Journal, v.99, p.18-22, 2007.

HILLEL, D. Fundamentals of soil physics. New York: Academic Press, 1980. 413p.

IMHOFF, S.; SILVA, A.P.; TORMENA C.A. Aplicações da curva de resistência no controle da qualidade física de um solo sob pastagem. Pesquisa Agropecuária Brasileira, v.35, p.14931500, 2000.

IMHOFF, S.; SILVA, A.P.; DEXTER A. Factors contributing to the tensile strength and friability of Oxisols. Soil Science Society of America Journal, v.66, p.1656-1661, 2002.

PERFECT, E.; KAY, B.D.; SILVA, E.P. Influence of soil properties on the statistical characterization of dry aggregate strength. Soil Science Society of America Journal, v.59, p.532-537, 1995.
RAHIMI, H.; PAZIRA, E.; TAJIK, F. Effect of soil organic matter, electrical conductivity and sodium adsorption ratio on tensile strength of aggregates. Soil and Tillage Research, v.54, p.145-153, 2000.

RUSSELLE, M.P.; ENTZ, M.H.; FRANZLUEBBERS, A.J. Reconsidering integrated crop-livestock systems in north America. Agronomy Journal, v.99, p.325-334, 2007.

SOIL SURVEY STAFF. Keys to soil taxonomy. 10 ed. Washington, D.C.: USDA/NRCS, 2006. Available at: http://soils.usda.gov/ technical/classification/taxonomy. Accessed 25 Jan. 2008.

STATISTICAL ANALYSIS SYSTEM INSTITUTE. SAS/STAT Procedure guide for personal computers; version 5. Cary: SAS Institute, 1999.

TORMENA, C.A.; FRIEDRICH, R.; PINTRO, J.C.; COSTA, A.C.S.; FIDALSKI, J. Propriedades físicas e taxa de estratificação de carbono orgânico num Latossolo Vermelho após dez anos sob dois sistemas de manejo. Revista Brasileira de Ciência do Solo, v.28, p.1023-1031, 2004.

TORMENA, C.A.; FIDALSKI, J.; ROSSI JUNIOR, W. Resistência tênsil e friabilidade de um Latossolo sob diferentes sistemas de uso. Revista Brasileira de Ciência do Solo, v.32, p.33-42, 2008.

WATTS, C.W.; DEXTER, A.R. Soil Friability: theory, measurement and the effects of management and organic carbon content. European Journal of Soil Science, v.49, p.73-84, 1998.

Received November 22, 2007 Accepted February 16, 2009 